\title{
Origins: Colonies and Statistics
}

\author{
Barbara Arneil ${ }^{\star}$ \\ Department of Political Science, University of British Columbia, C425 1866 Main Mall, Vancouver, BC, \\ V6T 1 Z1 \\ *Corresponding author. Email: arneil@mail.ubc.ca
}

Presidential Address for the Canadian Political Science Association, scheduled for the Annual Conference of the CPSA in June 2020, but never delivered because the conference was cancelled (in person and virtually) as a result of COVID-19.

\begin{abstract}
In this address, I examine the lexical, geographic, temporal and philosophical origins of two key concepts in modern political thought: colonies and statistics. Beginning with the Latin word colonia, I argue that the modern ideology of settler colonialism is anchored in the claim of "improvement" of both people and land via agrarian labour in John Locke's labour theory of property in seventeenth-century America, through which he sought to provide an ideological justification for both the assimilation and dispossession of Indigenous peoples. This same ideology of colonialism was turned inward a century later by Sir John Sinclair to justify domestic colonies on "waste" land in Scotland-specifically Caithness (the county within which my own grandparents were tenant farmers). Domestic colonialism understood as "improvement" of people (the "idle" poor and mentally ill and disabled) through engagement in agrarian labour on waste land inside explicitly named colonies within the borders of one's own country was first championed not only by Sinclair but also his famous correspondent, Jeremy Bentham, in England. Sinclair simultaneously coined the word statistics and was the first to use it in the English language. He defined it as the scientific gathering of mass survey data to shape state policies. Bentham embraced statistics as well. In both cases, statistics were developed and deployed to support their domestic colony schemes by creating a benchmark and roadmap for the improvement of people and land as well as a tool to measure the colony's capacity to achieve both over time. I conclude that settler colonialism along with the intertwined origins of domestic colonies and statistics have important implications for the study of political science in Canada, the history of colonialism as distinct from imperialism in modern political thought and the role played by intersecting colonialisms in the Canadian polity.
\end{abstract}

\section{Résumé}

Dans mon allocution, j'examine les origines lexicales, géographiques, temporelles et philosophiques de deux concepts clés de la pensée politique moderne-les colonies et la statistique. En partant du mot latin colonia, je soutiens que l'idéologie moderne du

(c) The Author(s), 2021. Published by Cambridge University Press. This is an Open Access article, distributed under the terms of the Creative Commons Attribution-NonCommercial-NoDerivatives licence (http://creativecommons.org/ licenses/by-nc-nd/4.0/), which permits non-commercial re-use, distribution, and reproduction in any medium, provided the original work is unaltered and is properly cited. The written permission of Cambridge University Press must be obtained for commercial re-use or in order to create a derivative work. 
colonialisme du peuplement s'enracine dans la prétention à l'« amélioration » à la fois des individus et des terres par le travail agraire selon la théorie de la propriété de John Locke dans l'Amérique du XVIIe siècle, par laquelle il a fourni une justification idéologique à l'assimilation et à la dépossession des Autochtones. Cette même idéologie du colonialisme a subi un siècle plus tard un retournement interne sous l'impulsion de sir John Sinclair pour justifier l'implantation de colonies domestiques sur les " friches incultes " d'Écosse-notamment Caithness (le comté où les ancêtres de ma famille étaient métayers). Le " colonialisme domestique ", dans l'optique de l' " amélioration " des individus (pauvres désœuvrés, malades mentaux et handicapés) par leur participation au travail agraire sur des terres en friche désignées explicitement de colonies à l'intérieur des frontières d'un même pays a été défendue non seulement par Sinclair mais aussi en Angleterre par son célèbre correspondant, Jeremy Bentham. Sinclair a simultanément forgé le mot statistique et a été le premier à l'utiliser en anglais. Le terme désignait la collecte scientifique de données d'enquêtes de masse visant à modeler les politiques de l'État. Bentham a également adopté le modèle statistique. Dans les deux cas, les statistiques ont été élaborées et déployées à l'appui de leurs plans visant les colonies domestiques afin de créer non seulement une référence et une feuille de route pour l'amélioration des individus et des terres, mais aussi un outil permettant de mesurer la capacité de la colonie à réaliser ces deux objectifs au fil du temps. Je conclus que le colonialisme de peuplement, conjugué aux origines entremêlées des colonies domestiques et de l'outil statistique, revêt des implications importantes pour l'étude de la science politique au Canada, de l'histoire du colonialisme par opposition à l'impérialisme dans la pensée politique moderne et du rôle tenu par les colonialismes intersectés dans la politique canadienne.

Keywords: colonies; statistics; political theory

Mots-clés : colonies; statistique; théorie politique

A CPSA presidential address often includes a combination of current research, autobiographical career retrospective and, if possible, larger insights into the discipline of political science and/or the Canadian polity. In this address, I hope to weave all three of these elements together. The main subject of my address is colonialism. In terms of a career retrospective, this topic stretches from my doctoral dissertation and first book, John Locke and America (1996), that analyzes Locke's theory of property as a defence of English settler colonization, to my most recent book, Domestic Colonies (2017), that analyzes the historical reality of thousands of colonies created within the borders of the colonizers' own state for fellow citizens (rather than over foreign peoples in foreign lands). Both kinds of colonies-settler and domestic-are justified, I argue, by the same colonial ideology first articulated by John Locke in the late seventeenth century, rooted in the principles of segregation, agrarian labour and improvement of people and land, in order, he argued, to create ethical benefits (make those deemed to be idle/irrational better/happier) and economic benefits (produce profits/revenues).

This address focuses on the origins of colonialism as an ideology and statistics as a methodology. As a historian of political thought, I believe origins are always of central importance: Where and when does a political idea originate? Who gave it voice and why? From here, one can trace its evolution. Political scientists who 


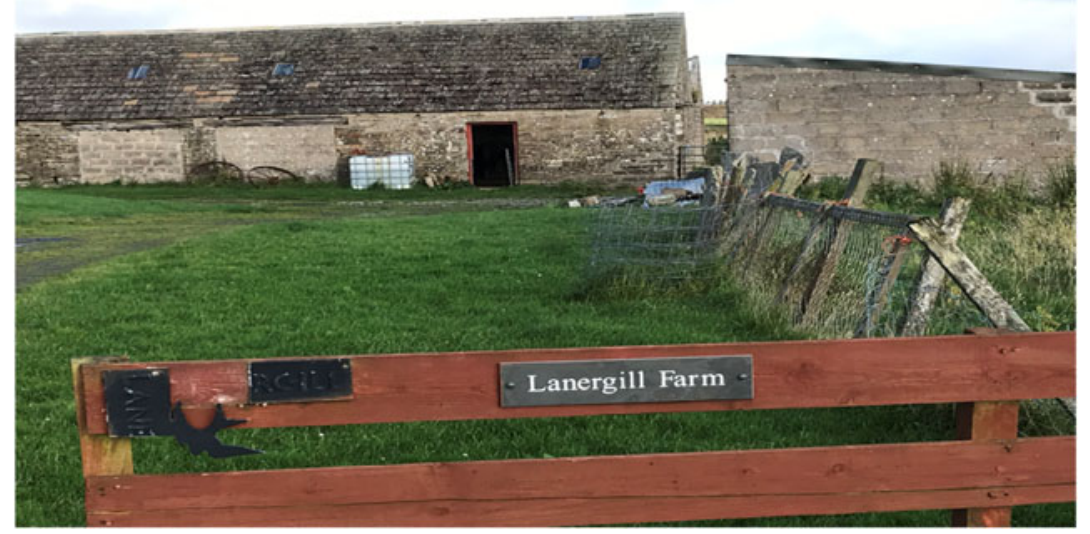

Figure 1 Lanergill Farm, Watten, Caithness. Photo by the author.

adopt a path dependency framework share this same focus on origins with respect to institutions and how they shape their evolution to the present day. I begin, however, with an autobiographical point of origin. Figure 1 is a photo of Lanergill Farm, near the village of Watten in Caithness, Scotland-the northernmost constituency in the British mainland.

On this farm, my maternal grandparents were tenant farmers on the laird's estate. My grandmother's family lived on or near this land for as far back as anybody remembers, and my mother was born in the farmhouse at Lanergill and, for the first decade of her life, lived like her ancestors had-without electricity, plumbing or running water. The distance between my life and my mother's early life is thus extraordinary and speaks to the velocity and scope of change over two generations. As tenant farmers on a croft, my grandparents were protected from eviction or clearances under the 1886 Crofters Act. The Highland Clearances, to which this Act was responding, were something my grandfather knew directly from previous generations and railed against on a regular basis. My aunt finally purchased Lanergill Farm from the laird in the 1970s, and my cousin continues to raise Cheviot sheep there.

While Caithness is as an autobiographical point of origin for me, I introduce it because, as I hope to demonstrate, it is the geographical origin of both statistics in the English language and domestic colonies. ${ }^{1}$ The key figure in both cases is Sir John Sinclair (1754-1835), a distant relative of Prime Minister Justin Trudeau through his mother. He was the MP for Caithness, founder and first president of the British Board of Agriculture and Internal Improvement, baronet of the Ulbster estate that included land from six of nine Caithness parishes (not Watten) and the author of the massive Statistical Accounts of Scotland (Sinclair, 1790-1791).

For the purposes of this address, origins can be defined in four distinct ways: (1) lexical origins, or etymology of the concept; (2) temporal origins, or when it first occurred; (3) geographic origins, or where it first occurred; and (4) philosophical 
Table 1. Colonies and Statistics-Four Kinds of Origins.

\begin{tabular}{|c|c|c|c|c|}
\hline & $\begin{array}{l}\text { Lexical origins: } \\
\text { Etymology }\end{array}$ & $\begin{array}{l}\text { Temporal origins: } \\
\text { When }\end{array}$ & $\begin{array}{c}\text { Geographic origins: } \\
\text { Where }\end{array}$ & $\begin{array}{l}\text { Philosophical origins: } \\
\text { Who }\end{array}$ \\
\hline $\begin{array}{l}\text { Settler } \\
\quad \text { colonialism }\end{array}$ & Latin: colonia & $15^{\text {th }}-17^{\text {th }} C$. & America & John Locke \\
\hline $\begin{array}{l}\text { Domestic } \\
\text { colonialism }\end{array}$ & Latin: colonia & $18^{\text {th }} \mathrm{C}$. & $\begin{array}{l}\text { Caithness } \\
\text { England }\end{array}$ & $\begin{array}{l}\text { John Sinclair Jeremy } \\
\text { Bentham }\end{array}$ \\
\hline Statistics & Latin: statisticum & $18^{\text {th }} \mathrm{C}$. & $\begin{array}{l}\text { Scotland } \\
\text { England }\end{array}$ & $\begin{array}{l}\text { John Sinclair Jeremy } \\
\text { Bentham }\end{array}$ \\
\hline
\end{tabular}

origins-who first introduced the concept and why (justifications for proposing it). Table 1 provides an overview of the address: the three key concepts are on the vertical axis-colonialism (settler/domestic) and statistics-and four kinds of origins are on the horizontal axis .

As you can see from the table, the philosophical origins of both domestic colonialism and statistics are intertwined in the writings of John Sinclair and his correspondent Jeremy Bentham, the great English utilitarian philosopher, and were intertwined conceptually-the one required the other.

In the first section, I begin with settler colonialism because it is the foundation of the ideology of colonialism as a whole, being both prior to domestic colonialism and a much more significant form of colonialism in modern Western history. Indeed, it is important to recognize this at the outset, because while I advance the argument there is shared ideological basis for domestic and settler colonies and I also shift the focus in this address to examine in depth domestic colonies and their interconnected origins with statistics, none of this should take away from the central historical fact that settler colonialism-exercised by white Europeans and later colonial settler states over racialized and Indigenous peoples and lands-is far and away the most important and profoundly damaging form of colonization in modern history. I hope my analysis of domestic colonies, including the current address that examines proposals by Sinclair and Bentham continues to expand, deepen and complicate our understanding of colonialism in all of its historical manifestations.

Domestic colonies thus provide us with an important new lens for distinguishing colonialism as an ideology from imperialism (contrary to the general view of postcolonial scholars that they are largely indistinguishable). ${ }^{2}$ While colonialism overlaps with imperialism historically and conceptually, the reality of domestic colonies proposed by Bentham and Sinclair in the eighteenth century in explicit opposition to imperialism and foreign colonies requires us to wrestle with the differences between the colonial and imperial in the history of Western political thought and practise. This distinction matters because it helps to explain, first, how colonialism was endorsed by virtually every progressive thinker from the seventeenth to early twentieth centuries even as they denounced imperialism; second, why colonialism was uniquely applied to so many different populations; and, most importantly, why and how colonialism rooted in the principles of segregation and improvement led to profoundly negative implications for those subject to it- 
from genocide within residential schools for Indigenous children to abuse in domestic colonies for paupers and the mentally ill and disabled.

\section{The Origins of Settler Colonialism}

\subsection{Settler colonialism: Lexical origins}

In ancient Rome, the word colonia meant "agrarian settlement" and was closely linked to the Latin words colere, meaning "cultivation (of the land)," and colonnus, meaning "farmer." Thus, colonization in the ancient world may be defined as a process of settling "excess" populations on "empty" land, separate from the "mother city" or metropole, and engaging them in agrarian labour in order to sustain themselves as an independent settlement. Defining colonization in this way does not encompass all forms of colonies or the multiple ways in which colonization and colonialism have evolved in meaning and are currently defined in scholarship. Rather, I seek to recover one single but critically important agrarian labour thread in the understanding of colonies and colonization-a thread that can be traced back to the earliest etymological origins of the word in Latin, through John Locke's defence of settler colonialism in the seventeenth century, up to domestic colonialism in the twentieth century. While present throughout, this particular thread of colonial thought is entirely absent from contemporary definitions of colonialism.

\subsection{Settler colonialism: Geographical and temporal origins}

The geographical and temporal origins of imperial colonialism are the Americas in the fifteenth to seventeenth century, with the Spanish and Portuguese first to colonize, followed by the British, French and other European powers. Justifications provided by Spanish natural law theorists like Francisco de Vitoria claimed the imperial power has the inherent right to travel through all lands in America, trade with whomever they wish and share in the wealth of the land "discovered." Moreover, if Indigenous peoples resist these rights, European imperial powers can make war and conquer them. Hugo Grotius argues on behalf of the Dutch government that the seas are free by natural law (against Portuguese and Spanish claims) and the right to land comes from occupation and a just war against men "who act like beasts" by trying to "re-claim" land occupied by European powers (Arneil, 1996). In both cases, imperialism and colonialism are almost synonymously understood as the right of conquest by the imperial victor. But John Locke's Two Treatises, which famously claims "in the beginning all the world was America," builds a defence of English colonization on an alternative set of ideological reasons. Thus we turn to the philosophical origins of settler colonialism in North America.

\subsection{Philosophical origins of settler colonialism}

In my PhD dissertation and first book (Arneil, 1996), I show that John Locke in the Two Treatises of Government provides, amongst other things, the original ideological justification for England's right to colonize America. Locke develops a new set of colonial arguments rooted in private property, improvement and agrarian 
labour, rather than imperial arguments rooted in war and conquest. Locke sought to justify the project of his patron, the Earl of Shaftesbury and the Lords Proprietor of Carolina, against majority opinion at home, which viewed colonization as fundamentally draining on the English treasury, as well as against English settlers in America (Rev. Roger Williams, for example) who challenged the ethical basis upon which England could dispossess Indigenous peoples of their lands.

Locke thus needed both an ethical and economic set of justifications to defend the right of England to colonize America. And the new settler colonial defence was settlers' agrarian labour on "waste," or uncultivated, land provided the right to claim land as private property in America based on both natural law and God's law. ${ }^{3}$

God gave the world to Men in Common... [but] it cannot be supposed he meant it should always remain common and uncultivated. He gave it to the use of the Industrious and Rational (and Labour was to be his Title to it). (Locke, 1988 975)

This quotation, along with multiple references in Chapter 5, "Of Property," of the Second Treatise to settler "cultivation," "enclosure" and husbandry-in contrast to custom-bound and "idle" Indigenous peoples, whose land lay "waste" or empty -anchor settler colonialism. As settlers' agrarian labour on supposedly waste land provides Locke with what he believes is an ideological defence of the dispossession of large swaths of territory and an economic justification for colonization (value will increase ten-, hundred-, one-thousand-fold for proprietors and those invested in it), it also provides an ethical justification better than imperialism; rather than conquering and dominating Indigenous peoples, the English settler wants to "improve" them from being idle and/or custom-bound to being industrious and rational.

Locke argues English settlers are "more improved" because of their industriousness and enjoy more conveniences as a result, whereas Indigenous peoples are idle and poor:

There cannot be a clearer demonstration of anything, than several nations of the Americans are of this, who are rich in land, and poor in all the comforts of life . . . for want of improving it by labour, have not one hundredth part of [what] we enjoy. (Locke, 1988: 9490)

Thus, unlike imperialist thinkers, Locke views Indigenous peoples not so much as inferior by nature to the English settler as backward by culture; but colonization can improve them:

Had the Virginian king Apochancana been educated in England, he [would be] as good... . The difference between him and a more improved English man lying barely in this, that the exercise of his Faculties was bounded within the Ways, Modes, and Notions of his own country. (Locke, 1975: 204)

Thus, for an Indigenous person, improvement means being segregated from their own people and customs: "educated in England" and being educated to 
change from within, to be taught to give up their "ways, modes, and notions," and adopt European arts, sciences and religion. Thus, imperialism justifies domination over those deemed inferior, but Lockean settler colonialism justifies improving land through labour (dispossession) and idle and custom-bound people via education and labour (assimilation).

Locke's arguments provide the three foundational principles of colonialism that will be deployed by foreign and domestic colonialists for centuries to come: segregation, agrarian labour and the improvement of land and people. Because colonialism, unlike imperialism, is rooted in words like labour and improvement rather than conquest and domination, the ideology is embraced by many progressive and "liberal" thinkers (Arneil, 2012, 2017, 2019) from the eighteenth to twentieth centuries, whether they use it to address the "idle and irrational" at home or overseas, claiming colonialism - unlike imperialism-will lead to both ethical benefits for the colonized ("improvement") and economic benefits for the colonizers.

\section{Origins of Domestic Colonialism}

\subsection{Lexical origins}

Colonia, rooted in cultivation of land, is the same lexical origin for domestic as settler colonialism. And the same principles of Lockean settler colonialism (segregation, agrarian labour and improvement) described above are redeployed in the eighteenth to twentieth centuries to justify colonies within the borders of one's own state for fellow citizens deemed to be idle (paupers, unemployed) and irrational (mentally ill and disabled). As I argue in recent research, specifically Domestic Colonies: The Turn Inward to Colony (Arneil, 2017), thousands of domestic colonies were proposed/created in Europe to transform the idle and irrational into, in Locke's famous words, "the industrious and rational." Thus, domestic colonialists argued, rather than charity, relief, imprisonment, constraint in asylums or transportation overseas, home colonies should be built on waste land to engage these populations in agrarian labour and create the same ethical and economic benefits claimed by settler colonialists (improving the person and creating revenues, respectively), meaning colonies will be less financially draining and more humane than the alternative solutions.

\subsection{Domestic colonialism: Temporal and geographical origins}

In Domestic Colonies, the geographic and temporal origins of domestic colonialism were identified as early eighteenth-century Holland through the Dutch philanthropist Johannes van den Bosch and his "Treatise" (1818), in which he argues his "cultivation system" in Java could be redeployed at home by transporting paupers from cities to domestic "colonies of benevolence" located on "waste" land-namely, the moors, heaths of Drenthe and in Belgium - to be engaged in agrarian labour. This proposal seemed to be original by adopting the principles of segregation, agrarian labour and improvement of people and land but deploying it on fellow Dutch citizens rather than foreign populations in the Dutch East Indies. It was also original by framing pauperism as a national-rather than local-policy issue needing a national philanthropic society. The Society of Benevolence under van den 
Bosch's leadership did create seven domestic colonies between 1820 and 1830 . Many other thinkers viewed van den Bosch as the original model; Alexis de Tocqueville and his coauthor G.D. Beaumont (1933) refer to van den Bosch as their model for their colonies agricoles in France, and J. S. Mill (1835) argued against home colonies by identifying Colonies of Benevolence in Holland as his model for a clear failure.

Identifying eighteenth-century Holland/Belgium as the temporal and geographical origin of domestic colonialism is common in the academic literature (Toth, 2006; Schrauwers, 2001, 2020; Arneil, 2017). They are also recognized as the original model in the international community; indeed, the Dutch and Belgian governments have built their bid to have UNESCO recognize these colonies as world cultural heritage sites on the argument that exactly because they are a point of origin for domestic colonies created in Europe throughout the eighteenth and early twentieth centuries, they are worthy of being recognized as original by the UN (Kingdom of the Netherlands and Kingdom of Belgium, 2017).

However, recent archival research would suggest that the geographical and historical origins of domestic colonies ought to be dated further back: to late eighteenth-century Scotland, specifically Caithness. Scottish historian Iain MacKinnon argues in a recent article that while my own analysis of domestic colonies is compelling, the original examples of such colonies were on John Sinclair's estate in the late eighteenth century:

Arneil's analysis suggests that domestic colonies are a development of the 19th century [but] her analysis can be drawn back at least a century further... . Sir John Sinclair of Ulbster. . . established colonies for wasteland agriculture on his Caithness estate in the 1790s. (MacKinnon, 2018: 43)

Domestic colonies were created on Sinclair's estate in three ways:

1. Cultivation of waste land: Transform large swaths of peat, bogs and moors "wasteland" in private estates into productive land while also providing employment to highland tenant farmers.

2. Remove tenant farmers from land they lived on in the Langwell Parish (near Sutherland) to colonies beside the ocean so they could fish herring and farm to make way for grazing land for the more lucrative Cheviot sheep (imported by Sinclair from Northern England). As John Henderson (1815) notes, Sinclair "removed the tenants. . . and placed them in new colonies near the sea shore." The Cheviot is central to the eighteenth-century Highland Clearances, and Sinclair pre-dated his cousin, the Duchess of Sutherland (whom Karl Marx famously rails against in his writings ${ }^{4}$ ), by 20 years and the clearance of 15,000 tenant farmers from her estate between 1811 and 1821 (Richards, 1999). While the Duchess and her factor engaged in driving people from their land and forcing them to go either south or abroad, Sinclair relocated his tenant farmers to new colonies with supplemental income from fishing.

3. Royal Colony of Scrabster: In the county report for Caithness, entitled General View of the Agriculture of the County of Caithness with 
Observations on the Means of its Improvement, authored by John Henderson (1815), an appendix was written by Sinclair, where he proposes a "Sketch of a Plan for establishing a Royal Colony at Scrabster" partly on Crown land and partly purchase of land from his own estate. He envisions a village of 100 houses, each with three acres and a cow, worked by spade. Surrounding these homes are 250 small farms of 10 acres each. "A portion of these commons will belong to the Crown as proprietor of the lands of Scrabster... . these allotments of waste lands may be appropriated by the Crown for so beneficial a purpose as that of forming new settlements for natives of the Highlands" (Sinclair, 1815a: 30). He concludes, "let this plan be compared with any scheme of foreign colonization and it will not be difficult to decide which is entitled to a preference" (32).

Sinclair concludes of his efforts in Caithness: "A foundation has thus been laid for a new system, not of foreign but of domestic colonization which will be found infinitely preferable to the cultivation of distant settlements" (1815b: 25).

\subsection{Philosophical origins of domestic colonialism}

As John Sinclair expanded the practice of domestic colonies on his own estate, he also sought to extend domestic colonization to the rest of Britain. Indeed his two main goals as founder and first president of the British Board of Agriculture and Internal Improvement was the enclosure of waste land / employment of paupers and the gathering of statistics to scientifically support how to do this best and measure improvement over time. Thus Sinclair proposes the first General Enclosure Act in 1796 and subsequent acts because domestic colonialism for all paupers required enough land to support an expanding population. Sinclair publishes various reports and essays where he develops arguments for domestic colonization. One of the key places to publish such essays was the Annals of Agriculture edited by Arthur Young, secretary to the Board of Agriculture while Sinclair was president. Both Young and Sinclair are the key interlocuters with Jeremy Bentham. Sinclair first writes Bentham on behalf of the BOA in July 1797 to ask him to write an essay on how best to manage British paupers.

Bentham responds immediately and enthusiastically to this request. In 1797, he published two tables through Arthur Young's Annals to collect data on paupers and then, in 1798, a series of excerpts from the first four books or chapters of his essay "Outline of a work Entitled Pauper Management Improved" in the Annals of Agriculture (Bentham, 1798). Bentham begins his essay by arguing that it should not be the local parish that solves pauperism but a national body. Moreover, it is not the state but a charitable organization that should run the colonies-the National Charity Company-a joint stock company to attract investors to provide financing based on the promise of future profits, rather than charge the public account. Bentham suggests between 250 and 500 Industry Houses, which he also described as pauper panopticons, with 2,000 paupers each, should be built on uncultivated waste land in England and absorb every pauper on relief. For Bentham, paupers include not only the poor and unemployed but widows, orphans, foundlings, the mentally and physically disabled-anybody who needs "relief" to 
survive. The central principle of Industry Houses, as the name would suggest, is labour rather than charity. Bentham specifically states that agrarian labour will be the "key activity," and it is to be done on "wasteland" (Bentham, 2010).

While it is clear in the substantive arguments he advances that Bentham is proposing a form of domestic colonization, in Book 5, he defends the idea in explicit terms. In a section entitled "Advantage of this Domestic Colony over Foreign Ones," he states: "To adopt the plan in question . . . would really be to colonize at home" and lists how domestic colonies are superior to foreign colonies for both economic reasons (profits from labour will stay in Britain, rather than drain the state via relief) and ethical reasons (improve paupers at home) (Quinn, 2010: 320).

This critique of foreign colonization and imperialism is repeated in various writings, including essays where he beseeches France to "Emancipate your colonies" (Bentham, 1793) and Spain to "Rid Yourselves of Ultramaria" (Bentham, 1995). He also argues within Britain that his panopticon proposal is preferable to transportation of paupers to foreign colonies, including in "Panopticon Vs. New South Wales" (Causer, 2019). Bentham's views are the opposite of his fellow British utilitarian, J. S. Mill, a strong proponent of imperialism who rejected domestic colonies: “The much vaunted 'Home Colonization' system of Belgium and Holland [Mill is referring to van den Bosch's colonies] which . . . plainly appears to be, what from general principles one might have predicted . . . a miserable failure" (Mill, 1835). It should be noted that Bentham in the last year of his life, realizing his panopticon would never be built, wrote an essay in defence of settler colonies in Australia to solve pauperism (Bentham, 2020). Thus, it is important historians of political thought recognize settler colonialism, domestic colonialism and imperialism as distinct ideologies; I return to this in my conclusion.

\section{Origins of Statistics}

The third and final section concerns the origins of statistics in the English language, which, it turns out, are very closely interwoven with the origins of domestic colonialism.

\subsection{Lexical origins}

The Latin term statisticum collegium means "council of state," so in its etymological origins, statistics referred to governance/policies of the state. In the modern era, the focus remained on governance and states, but the meaning of statistics evolved in the German term Statistik in the late eighteenth century, which meant "state affairs" or "state craft" informed by a "science" of politics-meaning scientific inquiries by learned men should be undertaken to help direct the affairs of the state and develop the best kind of policies.

\subsection{Temporal and geographic origins of statistics}

The first use of statistics in the English language, defined roughly the way we do today-a science based on the collection and analysis of aggregate data via 
surveys-is in Sir John Sinclair's late eighteenth-century Statistical Accounts of Scotland. For Sinclair, data was largely descriptive, based on written answers to questions on a national survey sent to ministers in all of the parishes about the land and people of Scotland. Jeremy Bentham embraces statistics, too, but seeks numerical rather than descriptive data via tables to collect the exact numbers of paupers in his 48 categories in each parish of England. Thus statistical analysis was born for the express purpose of serving internal improvement of both land and paupers - that is, domestic colonization. First, data will create a benchmark to measure any future improvement of land and people; second, scientific analysis of data will provide the needed information to design panopticons or colonies to maximize improvement of different groups, while ongoing collection of data once colonies are established can help staff to tweak how they are run. Finally, Sinclair and Bentham plan further surveys, so the time series allows internal improvement to be measured over time through different rounds of data collection.

\section{3a Philosophical origins of statistics: Sinclair}

John Sinclair first learnt about statistics in his travels to Germany in the 1870s but, as he himself argues, deploys it in a wholly original way compared to the German use of the term:

Many people were at first surprised, at my using the new words, Statistics and Statistical, as it was supposed, that some term in our own language, might have expressed the same meaning... Statistical is meant in Germany, an inquiry ... respecting matters of state; whereas, the idea I annex to the term, is an inquiry into the state of a country, for the purpose of ascertaining the... means of its future improvement... . I thought that a new word, might attract more public attention, I resolved on adopting it, and I hope that it is now completely naturalized and incorporated within our language. (Statistical Survey of Scotland, 1790-1791, Volume 20: xiii-xiv, emphasis added)

Sinclair collects data on people/land through a national survey for the express purpose of internal improvement. He hopes to identify best practices in terms of how to turn unimproved or idle people into more improved and industrious people and how to best turn uncultivated soil into more improved and productive land. Sinclair also argues he can establish a benchmark in each parish and thus measure improvement in future surveys. For Sinclair, statistics was not simply theory, but he implemented them in practice. Between 1790 and 1797, he created the first "big data" survey, known as the Statistical Survey of Scotland, which involved sending a survey of 171 questions to 803 parish ministers in Scotland. If he did not get a response from the minister, he sent a delegate to ensure he had a completed survey.

The origins of statistics and domestic colonization are thus profoundly interconnected for Sinclair, and a graphic demonstration of this connection is his "The Pyramid of Statistical Inquiry" (Figure 2; Sinclair, 1814b), with the raw data at the bottom of the pyramid being distilled as one moves upward through the three levels to ultimately produce, as he did, the British Code of Agriculture. 


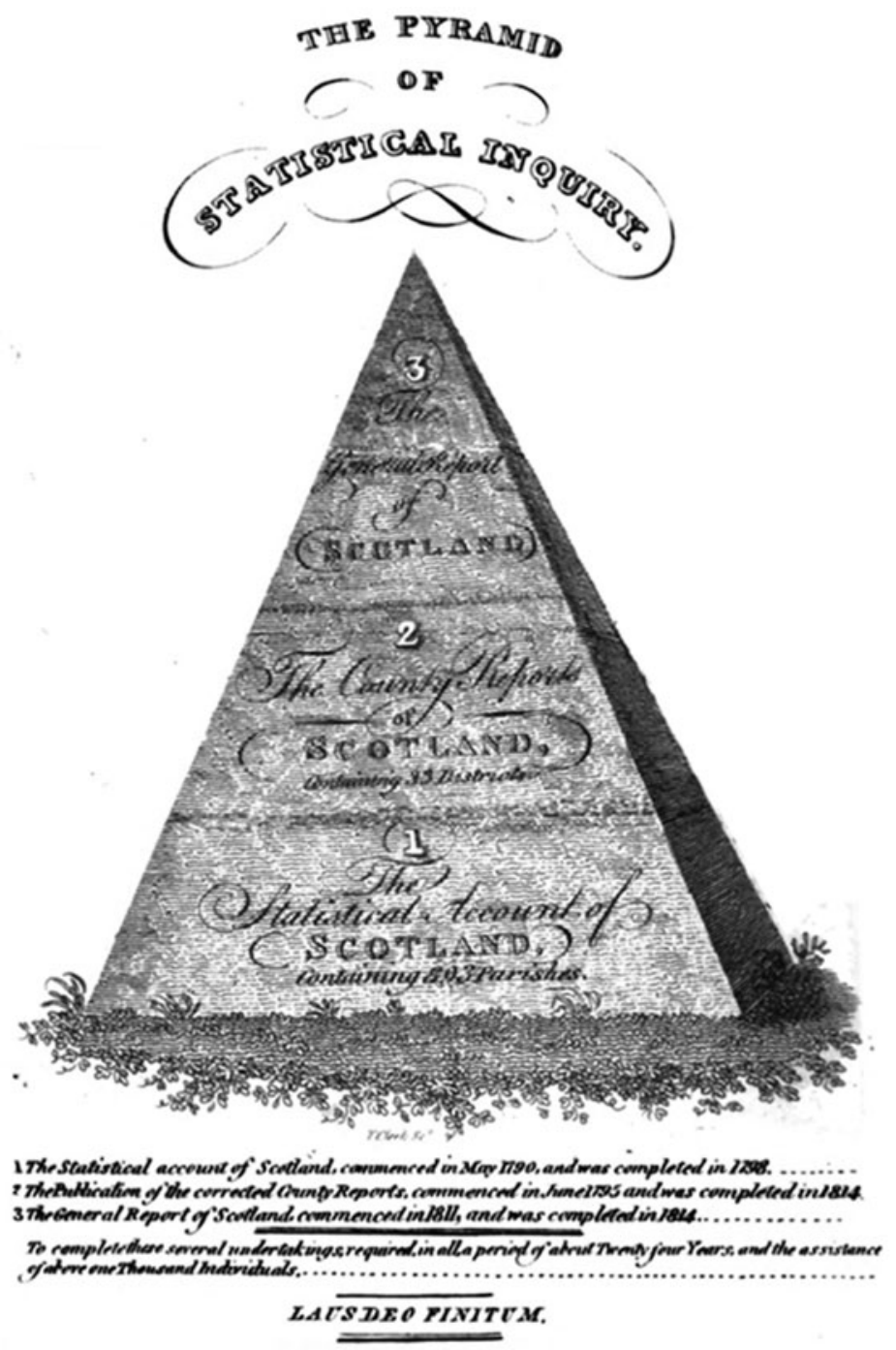

Figure 2 Sir John Sinclair's Pyramid of Statistical Inquiry, Statistic Accounts of Scotland.

Thus, at the bottom level of the pyramid (1) are the 803 Parish Reports from the Statistical Accounts of Scotland; at level (2), the parish reports are distilled into County Reports of Scotland (for example Henderson, 1815); which are further distilled (3) into a General Report of Scotland (Sinclair, 1814a) at the top of the pyramid. At each level, the data about land and population is used to provide recommendations on how to further the "internal improvement" of people and land, from parishes to counties to the country as a whole. Sinclair does publish many of the reports at each level, as well as the General Report for Scotland in 1814, under the official title Agricultural State and Political Circumstances of 
Scotland (which is where he first published the statistical pyramid) (Sinclair, 1814a). $\mathrm{He}$ concludes this report with the explicit endorsement of domestic colonization, based on data gathered with a specific focus on northern Scotland, where so much land, he argued, lay uncultivated (the crofters or tenant farmers would say it was being used and farmed in common). Thus, like Locke, the key to improvement is to colonize and create private allotments/property out of this common/ waste land. "To address the improvement of the more northern parts of Scotland is . . . to colonize at home"-a phrase redeployed by Bentham as described above (Sinclair, 1814a: 120).

The main vehicle at the end of the eighteenth century for propounding both domestic colonization and statistical science in Britain was the British Board of Agriculture and Internal Improvement (BOA) and the Annals of Agriculture. Sinclair's first goal for the BOA was a similar statistical survey in England as Scotland. The ultimate pinnacle, according to Sinclair, would be the creation of a single Code of Agriculture for Britain that would synthesize the two national reports. Although the English survey was never done, Sinclair had sufficient county reports from England that he published a Code of Agriculture in 1817. He concludes it as follows:

Among the various modes of improving wastes, that of bringing them into a state of cultivation by establishing colonies of labourers. . has been found beneficial to the proprietor and to the public ... thousands of acres [are] added to the national stock of arable land. . . multitudes [are] employed in reclaiming these wastes, occupation is provided for as many persons as are requisite... . In all these respects, the improvement of waste and unproductive land, is an object of very high national importance [which] requires attention [and] ... encouragement of the Legislature. (Sinclair, 1817: 167)

Statistics, for Sinclair, through the aggregation and analysis of massive survey data of people and land, founded a scientifically driven policy of domestic colonization. And thus domestic colonialism as a philosophy and survey-based statistics as a method were born together.

\section{3b Philosophical origins of statistics: Bentham}

Bentham shared Sinclair's and Young's belief that domestic colonization was anchored in statistical analysis, but Bentham pushed for parish-based numerical data on paupers; so the first thing he published after receiving the request from Sinclair to develop a plan for managing paupers in Britain were two tables-one with 48 different categories-to measure in each category exactly how many and what kinds of paupers lived in various parts of England. This numerical data was necessary, according to Bentham, for designing Industry Houses with specificity to the populations living there, as well as to measure their improvement over time. Thus he asked Arthur Young to publish the two tables in the 1797 Annals first, so readers would fill in parish-by-parish data on pauper population and the causes of relief before he published the excerpts of his essay in 1798-numbers came first for Bentham.

Statistics mattered to Bentham not only in preparing his model of Industry Houses but also because, once they were built, comprehensive data collected and 
recorded on each individual within the Industry Houses would help him implement and measure improvement:

Every circumstance by which the condition of an individual can be influenced, being remaked and inventoried nothing being left to chance, caprice or unguided discretion, everything being surveyed and set down in dimensions, number, weight and measure. (Bentham, 1798, 31: 172)

But ultimately, unlike Sinclair, Bentham never collected the data for his original tables and, despite lobbying for a decade on their behalf, never implemented his domestic colonies. Nevertheless, for Bentham, like Sinclair, collection of data and internal improvement of people and land in domestic colonies were inextricably linked to each other.

\section{Conclusions}

This analysis of the origins of colonies/colonialism (both domestic and settler) and statistics provides three insights into the Canadian polity, political theory and the discipline of political science. First, the polity of Canada, based on the preceding analysis, should be viewed as a site of intersecting settler and domestic colonialisms framed through Jodi Byrd's notion of cacophony. Second, the history of colonialism and imperialism in political thought should be recognized as leading to a different understanding of the relationship of the history of political thinkers in relation to both. Third, statistics and statistical method emerge out of specific historical contexts; and thus, within political science, this analysis asks whether, along with the central issue of numeracy and statistics, we should also teach the history. Let us consider each of these larger insights in turn.

\subsection{Polity of Canada: A cacophony of intersecting colonialisms}

Canada, as discussed, is rooted in the history of European imperial powers arriving on Indigenous territories and, later, sovereign states justifying their power through the ideology of settler colonialism. The origins of this ideology are John Locke's seventeenth-century defence of property rights. Locke argued that it was not imperial conquest that gave European metropoles the right to claim land and dispossess Indigenous peoples but settlers' labour on the "waste" or "empty" land that did. Moreover, Indigenous peoples are not seen as inferior to Europeans, for settler colonialists, but custom-bound, prevented from being fully "improved" in body and mind by their "ways, modes, and notions." If "educated in England"-segregated from their home communities and broken free from their cultural ways of being and thinking - they could change from within. Settler colonialism is defended in seemingly more progressive terms-embracing universal notions of improvement of all land and peoples, while rejecting conquest and domination. In reality, the power unleashed by colonialism provided an ideological foundation for both the dispossession and removal of Indigenous peoples from their territories deemed to be "empty" and the assimilation of Indigenous peoples through a specific kind of "education" directed at extinguishing their collective cultural being. 
So underpinning Canada is this original process of settler colonization rooted in the ideological defence of Locke that makes "terra nullius" the central claim of the Canadian state in taking over ever more expansive lands and the principle of extinguishing the "Indian in the Indian" the basis of the residential school. But while Canada is constituted at a foundational level on settler colonization, within that process were created specific domestic colonies, particularly across the Prairies for various groups of citizens deemed to be "idle" and "irrational," as well as persecuted religious minorities in Europe. Thus in the Prairies, in particular, one finds Mennonites located on reserves in Manitoba, within which they engaged in agrarian labour to improve themselves and the land; Jewish farm colonies in Alberta and Saskatchewan dedicated to the same end; and Doukhobor colonies (North and South Colony) in Saskatchewan created and funded by Leo Tolstoy and Peter Kropotkin. Each of these groups were fleeing persecution in Europe but, in creating new colonies in Canada, engaged themselves in processes of dispossession and settler colonization. What is important to note here is how the domestic colonies of Doukhobors, for somebody like Kropotkin, were seen as vehicles through which to challenge capitalism, private property, the sovereignty of the state itself and bring in a society governed by the principles of collective anarchy. Thus colonialism can be both domestic and settler; it can be advocated by anarchists as well as conservatives, liberals as well as republicans, secularists as well as deeply religious people-but at its heart is an ideological belief in agrarian labour, segregation and improvement of both people and land. Across Canada, domestic farm colonies were also created for mentally ill and disabled citizens at the beginning of the twentieth century.

The best formulation for how colonialism in a country like Canada can be framed-given these various ideological commitments and existence of different intersecting kinds of domestic and settler colonialism-is Indigenous scholar Jodi Byrd's notion of cacophony:

In geographical localities of the Americas, where histories of settlers and arrivants map themselves into and on top of indigenous peoples, understanding colonialism as a cacophony of contradictorily hegemonic and horizontal struggles offers an alternative way of formulating and addressing dynamics that continue to affect peoples as they move and are made to move within empire. (Byrd, 2011: 53)

The "hegemonic and horizontal struggles" of both "settler and arrivants"whether Doukhobors who move voluntarily but under severe persecution at home into domestic colonies in Saskatchewan; or the paupers who are transported from Britain rather than housed in domestic colonies, as Bentham and Sinclair are arguing; or the mentally ill and disabled in Canada who were "made to move" on top of Indigenous territories-all represent clashes in relation to both the process of settler colonization and different forms of colonalisms (utopian, settler, domestic colonialism focused on either the "irrational" or the "idle poor") and create a set of dynamics that we continue to struggle with today. Underpinning it all, as Byrd makes clear, is the original dispossession and assimilation of Indigenous peoples in order for any of the other colonialisms to occur in the Canadian polity. 
Table 2. Key European Thinkers: Support for Colonialism versus Imperialism.

\begin{tabular}{llll}
\hline & Imperialism & Settler colonialism & Domestic colonialism \\
\hline John Locke & $\boldsymbol{x}$ & $\checkmark$ & NA \\
Jeremy Bentham & $\boldsymbol{x}$ & $\boldsymbol{x}$ & $\checkmark$ \\
Alexis deTocqueville & $\checkmark$ & $\checkmark$ & $\checkmark$ \\
J. S. Mill & $\checkmark$ & $\checkmark$ & $\boldsymbol{x}$ \\
Peter Kropotkin & $\boldsymbol{x}$ & $\checkmark$ & $\checkmark$ \\
\hline
\end{tabular}

\subsection{Insights for political theory and the history of political thought}

There are two main insights for political theory of this analysis. The first is to abandon the almost universally accepted idea in post-colonial analysis that colonialism and imperialism are indistinguishable; while they often overlap, they can and must be distinguished. This is important because colonialism is animated-in its domestic as well as foreign settler form - by a pernicious kind of internalized power that is distinct from imperialism. Rather than dominating from above, colonialism requires change from within, rooted in the twin principles of "improvement" (providing fertile ground for colonial powers to justify violating physical and mental boundaries of the colonized) and "segregation" (providing impunity to those who wish to abuse, since they are beyond any oversight of society). The centrality of improvement to the ideology of colonialism also helps to explain why so many progressive political theorists champion it in the eighteenth and early twentieth centuries (anarchists, socialists and liberals), even as many of them rail against imperialism understood as dominating/conquering people and lands.

The second implication of this analysis for political theorists is to rewrite the history of Western political theory in relation to three distinct threads of thoughtdomestic colonialism, settler colonialism and imperialism. Specific thinkers can endorse one or two of these ideological claims while explicitly rejecting the others. And the history of Western political thought suggests the combinations are varied. Table 2 summarizes various possible combinations in four leading thinkers.

John Locke opposed conquest and imperial justifications in favour of settler colonial justifications for American colonization-rooted in agrarian labour on "empty" land. Sinclair and Bentham defend domestic colonies in explicit opposition to foreign imperial colonies. Rather than exporting people, labour and money overseas, why not have them work on waste land at home and ensure profits remain in Britain? Bentham is thus a liberal utilitarian thinker who is antiimperialist, anti-settler colonialist (until the last year of his life) but pro-domestic colonialist. His fellow liberal utilitarian thinker, J. S. Mill, is pro-imperalist in India, pro-settler colonialist in Canada-as Duncan Bell has shown in recent writings (2016) - but explicitly anti-domestic colonialist in his published writings on the English Poor Laws. French republican and democratic philosopher Alexis de Tocqueville is pro-imperialist in Algeria, pro-settler colonialist in America and pro-domestic colonialist in his defence and financial support of colonies agricoles in France. Anarchist and socialist Peter Kropotkin negotiated Doukhobor domestic colonies in Canada and is thus pro-domestic colonialist and pro-settler colonialist, for to exist at these domestic colonies required prior dispossession of Indigenous 
peoples in Saskatchewan, but he is also anti-imperialist (Doukhobors were escaping imperial Russian power) and even anti-state. Put simply, the "canon" of political thinkers would be reimagined if domestic and settler colonialism were both recognized and distinguished from imperialism.

\subsection{Discipline of political science}

Political scientists have a central obligation to teach students statistics and statistical method so they can, as citizens, independently and critically understand the polls that dominate our political world and analyze premises, inferences and/or causal claims and validity through their undergraduate and graduate degrees. Thus, first and foremost, we need to teach numeracy with respect to statistics and statistical method. But my analysis poses the question whether, alongside numeracy, we should also teach historical context: Why did statistics emerge when they did and why do statistical methods advance at particular moments in history? I have shown that the birth of statistics was intertwined with the first domestic colonies in Scotland; the justification for each intertwined with the other through the principle of "improvement." But if we go further and trace statistical method to the twentieth century, we find more defenders of internal improvement and domestic colonies who used statistical science to further their colonial ideological ends.

The first of these, labour economist Charles Booth, advances statistical method in industrialized London in order to measure the levels and kinds of poverty and provide statistical support for his recommendation of labour colonies in England for the poorest decile (Booth, 1888). At the beginning of the twentieth century, eugenicists Francis Galton and Karl Pearson developed the methods of standard deviation and Pearson coefficient, respectively, to measure abnormality in people Bentham called paupers (the poor, disabled, criminals, and so on), in order to scientifically undergird their recommendations for state eugenics, including segregation in colonies and sterilization (Davis, 1997).

Thus, Galton and Pearson, as the first and second Chair of Eugenics, respectively, at University College London's groundbreaking Department of Applied Statistics (the first in the world) inextricably linked together advances in statistical methods and eugenicist policies. Galton supported the colony model as recommended by the Royal Commission on the Feeble-Minded in 1905 because it served the purpose of segregating the "unfit" from society and each other by gender, thus preventing reproduction of those deemed to be "abnormal" on his "normal curve." He also was a supporter of sterilization as a more effective tool to prevent reproduction. Statistics allowed Galton and Pearson to identify who was "abnormal" in comparison to the "normal" curve of intelligence (Davis, 1997). The history of statistics, including the specific methodological advances made, are both interwoven with the defence of colonization and required by it. Statistics explicitly allowed those who support domestic colonization to identify who should be colonized in what specific ways, creating benchmarks and tools for measuring improvement in the "idle," "irrational" and backward members of society and creating an argument in relation to states that their recommendations were rooted in a scientific analysis of the 
numbers. Given this history, one wonders if it might not be taught to students alongside the teaching of numeracy and method.

Ultimately in this address on "origins," I hope to have demonstrated that "history matters," and the origins of concepts matter the most as we trace their evolution through time. In analyzing the origins of colonialism, statistics and the intertwined births of the former in its domestic variant and the latter in its earliest usage in the English language, I have argued the lexical, geographical, temporal and especially philosophical origins of these concepts create profound impacts for Indigenous peoples around the globe subject to assimilation and dispossession but also paupers, the mentally ill and disabled segregated in domestic colonies. This analysis thus creates new insights into the subdiscipline of political theory by producing a more complicated history of key political thinkers in relation to both colonialism and imperialism, suggests teaching statistics within political science may require the teaching of history along with the central lessons of numeracy, and produces a more complicated and cacophonous story of intersecting colonialisms in settler colonies such as the polity of Canada.

\section{Notes}

1 From a political science and electoral behaviour perspective, the county of Caithness is best known as a political outlier, as it repeatedly bucks larger trends in Scotland and UK in national elections. In the recent (2019) election, Caithness elected a Liberal Democratic Member of Parliament (MP), while the vast majority of Scottish constituencies voted in Scottish National Party (SNP) MPs, and the UK elected a majority of Conservative MPs. This pattern is not a one-off; for six out of the last seven elections, Caithness elected a Liberal Democrat rather than an SNP, Labour or Conservative MP.

2 Margaret Kohn in the Stanford Encyclopedia of Philosophy defines colonialism as the "practice of domination, which involves the subjugation of one people to another," noting "one of the difficulties in defining colonialism is that it is hard to distinguish it from imperialism. Frequently the two concepts are treated as synonyms" (Kohn, 2017). Jennifer Pitts argues, in her overview of colonialism and imperialism in Western political theory, that it is impossible to "distinguish systematically between the imperial and colonial" (Pitts, 2010: 213-14).

3 Of course, Locke is historically inaccurate to say land was lying waste or uncultivated in many cases, which he himself knew from his own library. Indeed there are many historical accounts of Indigenous peoples teaching Europeans how to grow crops native to the Americas. Casting land as empty or waste is, however, necessary to the ideological requirements of colonialism. Similarly, viewing Indigenous peoples as idle is also a historically constructed ideological claim necessary to justify dispossession. This image of the idle or custom-bound/irrational Indian on terra nullius has remained a racist trope within settler colonial nations until today.

4 Marx writes about the Duchess of Sutherland explicitly in his New York Tribune article (Marx, 1853) and about the highland clearances in relation to primitive accumulation in Volume 1 of Capital, where he states: "What 'clearing of estates' really and properly signifies, we only learn in the promised land of modern romance, the Highlands of Scotland. There the process is distinguished by its systematic character, by the magnitude of the scale on which it is carried out at one blow" (Marx, 1992: 890).

\section{References}

Arneil, Barbara. 1996. John Locke and America: A Defence of English Colonialism. Oxford: Oxford University Press.

Arneil, Barbara. 2012. "Liberal Colonialism, Domestic Colonies and Citizenship." Journal of the History of Political Thought 33 (3): 491-523.

Arneil, Barbara. 2017. Domestic Colonies: The Turn Inward to Colony. Oxford: Oxford University Press. 
Arneil, Barbara. 2019. "The Failure of Planned Happiness: The Rise and Fall of British Home Colonies." In Happiness and Utility: Essays Presented to Frederick Rosen, ed. Georgio Varouxakis and Mark Philp. London: University College London Press.

Bell, Duncan. 2016. Reordering the World: Liberalism and Empire. Princeton: Princeton University Press.

Bentham, Jeremy. 1793. "Emancipate your Colonies!" An Address to the National Convention of France. London: C. and W. Reynall, for Robert Heward, 1830.

Bentham, Jeremy. 1798. "Outline of a Work entitled Pauper Management Improved." In Annals of Agriculture and Other Useful Arts, ed. Arthur Young. Vol. 30: 89-176, 241-96, 393-424, 457-504; Vol. 31: 33-64, 169-200, 273-88.

Bentham, Jeremy. 1817. The Code of Agriculture. London: Sherwood, Neely and Jones.

Bentham, Jeremy. 1995. "Rid Yourselves of Ultramaria." In The Collective Works of Jeremy Bentham: Colonies, Commerce and Constitutional Law: Rid Yourselves of Ultramaria and Other Writings on Spain and Spanish America, ed. Philip Schofield. Oxford: Oxford University Press.

Bentham, Jeremy. 2010. "Pauper Management Improved." In vol. 2 of The Collected Works of Jeremy Bentham: Writings on the Poor Laws, ed. Michael Quinn. Oxford: Oxford University Press.

Bentham, Jeremy. 2020. "Colonization Company Proposal." In The Collected Works of Jeremy Bentham: Panopticon versus New South Wales and Other Writings on Australia, ed. Tim Causer and Philip Schofield. UCL Bentham Project. Oxford: Oxford University Press.

Booth, Charles. 1888. "Conditions and Occupations of the People of East London and Hackney, 1887." Journal of the Royal Statistical Society 51: 276-339.

Byrd, Jodi. 2011. "Been to the Nation, Lord, but I Couldn't Stay There: American Indian Sovereignty, Cherokee Freedmen and the Incommensurability of the Internal." Interventions: International Journal of Postcolonial Studies 13(1):31-52.

Causer, Tim. 2019. "'The evacuation of that scene of wickedness and wretchedness': Jeremy Bentham, the Panopticon and New South Wales, 1802-1803." Journal of Australian Colonial History 21: 1-24. https:// discovery.ucl.ac.uk/id/eprint/10085007/.

Davis, Lennard J. 1997. "Constructing Normalcy: The Bell Curve, the Novel, and the Invention of the Disabled Body in the Nineteenth Century." Disability Studies Reader, ed. Lennard J. Davis. New York: Routledge.

Henderson, Captain John. 1815. General View of the Agriculture of the County of Caithness with Observations on the Means of its Improvement. County Report for Caithness for Board of Agriculture and Internal Improvement. London: Board of Agriculture and Internal Improvement.

Kingdom of the Netherlands and Kingdom of Belgium. 2017. Colonies of Benevolence: World Heritage Nomination. Nomination File for Inscription on the UNESCO World Heritage List. Steering Group Colonies of Benevolence on the Way to World Heritage. https://www.kolonienvanweldadigheid.eu/ sites/default/files/CofB_I_NominationFile_0.pdf.

Kohn, Margaret. 2017. "Colonialism." Stanford Encyclopedia of Philosophy. http://plato.stanford.edu/ entries/colonialism/. First published May 9, 2006; substantive revision August, 2017. Stanford: Metaphysics Research Lab Center for the Study of Language and Information, Stanford University.

Locke, John. 1988. Two Treatises of Government, ed. Peter Laslett. Cambridge: Cambridge University Press.

Locke, John. 1975. Peter Niddtich, ed. An Essay concerning Human Understanding. Oxford: Clarendon Press.

MacKinnon, Iain. 2018. "Colonialism and the Highland Clearances." Northern Scotland 8 (1): 22-48.

Marx, Karl. 1853. "The Duchess of Sutherland and Slavery." The People's Paper, no. 45, March 12.

Marx, Karl. 1992. Capital: A Critique of Political Economy. Vol. 1. Penguin Classics.

Mill, J. S. 1835. Response to Nassau William "Senior's Preface to the Foreign Communications Poor Law Report." Globe and Traveller, June 22, p. 2.

Pitts, Jennifer. 2010. "Political Theory of Empire and Imperialism." Annual Review of Political Science 13: 211-35.

Quinn, Michael, ed. 2010. The Collected Works of Jeremy Bentham: Writings on the Poor Laws. Vol. 2. UCL Bentham Project. Oxford: Oxford University Press.

Richards, Eric. 1999. Patrick Sellar and the Highland Clearances: Homicide, Eviction and the Price of Progress. Edinburgh: Polygon. 
Schrauwers, Albert. 2001. "The 'Benevolent' Colonies of Johannes van den Bosch: Continuities in the Administration of Poverty in the Netherlands and Indonesia." Comparative Studies in Society and History 43 (2): 298-328.

Schrauwers, Albert. 2020. "Colonies of Benevolence: A Carceral Archipelago of Empire in the Greater Netherlands." History and Anthropology 31 (3): 352-70.

Sinclair, Sir John. ed., 1790-1791. The Statistical Accounts of Scotland Drawn Up From the Communications of the Ministers of Different Parishes. 21 vols. Edinburgh: William Creech. https://stataccscot.edina.ac.uk/ static/statacc/dist/home.

Sinclair, Sir John. 1814a. General Report of the Agricultural State, and Political Circumstances, of Scotland. Edinburgh.

Sinclair, Sir John. 1814b. "The Pyramid of Statistical Inquiry." General Report of the Agricultural State, and Political Circumstances, of Scotland. Vol. 3. Edinburgh: Constable.

Sinclair, Sir John. 1815a. "Accounts of the Improvements carried out in the Country of Caithness for the years 1801, 1802, 1803." Appendix no. 1 in General View of the Agriculture of the County of Caithness with Observations on the Means of its Improvement. County Report for Caithness written by Captain John Henderson. London: Board of Agriculture and Internal Improvement. (Appendices: 1-32).

Sinclair, Sir John. 1815b. "An Account of the Improvements Carried on [by Sinclair] on his estates in Scotland." Appendix no. 2 in General View of the Agriculture of the County of Caithness with Observations on the Means of its Improvement. County Report for Caithness written by Captain John Henderson. London: Board of Agriculture and Internal Improvement. (Appendices: 33-76).

Sinclair, Sir John. 1817. The Code of Agriculture. 1st ed. London: Sherwood, Neely and Jones.

Tocqueville, Alexis de and Gustave de Beaumont. 1833. On the Penitentiary System in the United States and its Application in France with an Appendix on Penal Colonies, and Also, Statistical Notes. Philadelphia: Carey, Lea \& Blanchard.

Toth, Stephen A. 2006. Beyond Papillon: The French Overseas Penal Colonies, 1854-1952. Lincoln: University of Nebraska Press.

van den Bosch, Johannes. 1818. Verhandeling over het mogelijkheid, de beste wijze vaninvoering en de belangrijke voordeelen eener Algemeene Armeninrigting in het Rijk der Nederlanden, door het vestigen eener Landbouwende Kolonie in deszelfs No-ordelijk gedeelte. (Translation: Treatise on the Possibility, the Best Method of Introduction and the Important Advantages of a General Poor Establishment in the Empire of the Netherlands, by Establishing an Agricultural Colony in its No-orderly Part). Amsterdam

Cite this article: Arneil B (2020). Origins: Colonies and Statistics. Canadian Journal of Political Science 53, 735-754. https://doi.org/10.1017/S000842392000116X 